major drawbacks of portfolios is that evaluation criteria must be generated by the department in line with the goals it has set for student learning. Over the summer, I developed a checklist for evaluation of the senior thesis that borrows heavily from materials used by Beaver faculty in other departments. For portfolios, we need questions that deal with the connections between courses, experience, and the thesis as perceived by the student and that allow the evaluator to comment on the student's development in terms of specific skills and his/her ability to engage in self-assessment.

This year, we will use the senior thesis evaluation forms, adding an open-ended question directed to the portfolios as a whole. Copies of evaluation forms will be sent to students, and the evaluator will continue to write a letter providing overall feedback to the department. The letter and the forms for each senior will become part of the assessment materials for the department. This year, in connection with our department review, we hope to finalize the assessment program. We will reexamine the portfolio format, revise the evaluation criteria, if necessary, and, if possible, determine what other information we need to collect for a complete picture of student learning in the major.

Another project for the future is the handbook for political science majors that was suggested by the Wahlke task force (1991, p. 57). It would enable us to build identification with the program, further promote experiential learning and encourage students to start thinking sooner about goals and outcomes for themselves. We use the APSA career booklet for undergraduate political science majors now, but not until senior seminar.

For faculty, getting involved in assessment is time consuming and it means holding ourselves accountable. "Accountability here means delivering an education equal to that promised in recruitment, to the student's investment (not only of money but of time and effort), and to the demands of the student's postcollegiate life" (Hutchings 1990b, p. 8). If we as political scientists do not get more involved, however, we will forfeit the opportunities that exist now for influencing the process. For in political science as in other disciplines, 'what's most at stake here are educational values. Choosing portfolios is choosing to enact-and communicate to students-a view of learning as involving, personal, connected, and ongoing"' (Hutchings 1990a, p. 8).

\title{
A Report on the Advanced Placement Program in Political Science
}

\author{
Frank L. Wilson, Purdue University
}

This year marked the fifth year of the College Board's Advanced Placement Program in Government and Politics. This program offers high school students the opportunity to earn college level credit for two standard political science courses: "Introduction to U.S. Government and Politics" and "Introduction to Comparative Politics." The courses are offered in the high schools by teach- ers who follow college curricula and use college level textbooks. At the end of the school year, students who wish to establish college credit take a nation-wide examination, which includes both multiple-choice and free-response questions. The essay portion of the exam is graded by college and high school instructors.

While only five years old, the Government and Politics Program has

\section{References}

Hutchings, P. 1989. "Linking Assessment and Teaching." Assessment Update 1: 8-11.

1990a. "Learning Over Time: Portfolio Assessment." American Association for Higher Education Bulletin April: 5-8. $1990 \mathrm{~b}$. "Assessment and the Way We Work." Fifth AAHE Conference on Assessment Closing Plenary Address June: 1-8.

Hutchings, P. and E. Reuben. 1988. "Faculty Voices on Assessment." Change JulyAugust: 48-55.

Julian, F., D. Chamberlain, and R. Seay. 1991. "A National Status Report on Outcomes Assessment by Departments of Political Science." PS: Political Science \& Politics June: 205-08.

Schneider, C. 1989. "Using External Examiners to Assess Student Learning in Arts and Sciences Majors." Association of American Colleges Project Report August: 1-16. (produced for discussion purposes only, not quoted)

Wahlke, J. 1991. "Liberal Learning and the Political Science Major: A Report to the Profession." PS: Political Science \& Politics March: 48-60.

\section{About the Author}

Joan Hulse Thompson, assistant professor at Beaver College, co-chairs the political science department with her husband, Robert R. Thompson. Her major research interest has been the Congressional Caucus for Women's Issues, and she served as an APSA Congressional Fellow, 1985-86. already established itself as an important part of political science. The program has proved to be one of the most popular and most rapidly growing subjects in the Advanced Placement curriculum. The first year, 1987, over 8,000 took the examination. In 1991, roughly 21,000 took the Advanced Placement exams in Government and Politics, and many thousands others took the course 
without taking the examination. Over 60 college and high school instructors participated in the exam reading session in June 1991 at Trenton State College. Many colleges and universities across the country now accord credit or advanced placement for students who succeed in this examination.

There will be a major change in the format of the AP exam in Government and Politics that will come into effect for the 1993 test. Instead of the current exam format with two 90-minute exams, starting with the 1993 examinations there will be two 120-minute exams: one two-hour exam in U.S. Government and Politics and one two-hour exam in Comparative Politics. Students will be able to take one or both exams for the standard examination fee.

The U.S. exam will have the following components:

- 60 multiple-choice questions (45 minutes $-50 \%$ of the AP grade)

- 1 essay question (45 minutes$30 \%$ of the AP grade)

- 2 short-answer questions based on stimuli such as tables, graphs, quotations, or cartoons (30 minutes $-20 \%$ of the AP grade).

The Comparative exam will have the following components:

- 60 multiple-choice questions (45 minutes $-50 \%$ of the AP grade)

- 1 essay question (45 minutes$30 \%$ of the AP grade)
- 1 short-answer question focused on a developing country-India, Mexico, or Nigeria (30 minutes$20 \%$ of the AP grade).

The changes in the examination content will allow a better assessment of the students' abilities. It will also increase the reliability of grading of the free-response essays.

If you would like information about the Advanced Placement Course in Government and Politics or if you would be interested in serving as an examination reader, contact Stephen Lazer or Claire Melican at Educational Testing Service, (609) 921-9000), extensions 1480 or 1940. Please feel free to call collect.

\section{Re-Forming the Major: Principles, Practices and Politics}

Two regional conferences to help faculty, department chairs, and academic administrators consider the place and function of programs of concentrated study-"majors"-in terms of their contribution to the larger goals of undergraduate education.

The conferences will be held in

Philadelphia: February 20-23, 1992

Chicago: March 26-29, 1992

Drawing on the analysis of AAC's recent report, The Challenge of Connecting Learning, each conference will address such key issues for strengthening majors programs as communities for liberal learning, including:

- developing the faculty's collegial responsibility for the major;

- encouraging connected learning within and beyond the major;

- connecting the major with general education;

- fostering the inclusion and achievement of different types of students in the major; and

- building assessment into curricular and program structures.

Invited speakers include:

- Gavriel Salomon-Professor of Education, University of Arizona

- Jonathan Smith-Distinguished Professor of the Humanities; University of Chicago

- John Thorpe-Vice Provost for Undergraduate Education, SUNY Buffalo

- Blythe Clinchy-Professor of Psychology, Wellesley College

For more information, contact Carol Schneider or Thomas Jeavons at the Association of American Colleges, $1818 \mathrm{R}$ Street, NW, Washington, DC 20009; (202) 387-3760. 